\title{
CAUSAL OR EFFECTUAL? AN EXPLORATORY STUDY ON WOMEN'S ENTREPRENEURIAL BEHAVIOR AND DECISION-MAKING LOGIC
}

\author{
Annie Banikema ${ }^{1 *}$, Thrycia Tite ${ }^{2}$ \\ ${ }^{1}$ LITEM, University of Evry, IMT-Business School, University Paris-Saclay, France. \\ ${ }^{2}$ IUT Evry, France. \\ *Corresponding author. Email: a.banikema@iut.univ-evry.fr
}

\begin{abstract}
Basing on the principle of causation vs effectuation, we try in this research to undersantand women's entrepreneurial process and their decision-making logic in the process of entrepreneurial action. Specifically, we seek (1) to understand under what conditions female entrepreneurs mobilize effectual rationality or causal rationality to make decisions and act and (2) to explain the preference for causal or effectual behavior among female entrepreneurs. Research method includes a qualitative approach, through In-depth and semi-structured interviews. Those were conducted with 10 female entrepreneurs, at different stage of their entrepreneurial process, and analyzed through a content analysis. Consistent with existing literature, our results highlight variables that can potentially influence the use of effectual or causal logic: Entrepreneurial expertise and entrepreneurial uncertainty. More interesting this research points out the link between entrepreneurial motivations and the type of decision-making logic used by female entrepreneurs.
\end{abstract}

Keywords: Female entrepreneurs, effectuation, causation, entrepreneurial motivations.

\section{Introduction}

For many years, the principle of causation has been the dominant trend in entrepreneurship research (Perry, Chandler, \& Markova, 2012). This principle considers that individuals in their entrepreneurial process are guided by rational and objective-oriented behavior. It is only very recently that effectuation has been proposed as a new theoretical perspective to understand the decision-making logic of entrepreneurs and their behaviour in the construction of their entrepreneurial process (Sarasvathy, 2008). Despite the density of this research field, none of them specifically focused on women entrepreneurs and their decision-making type in relation to these two logics. It is interesting in this viewpoint, to investigate specifically how women build their entrepreneurial path, for there is a general consensus about the differences between men and women as far as entrepreneurship is concerned.

Causation and effectuation represent two distinctive framework applicable to understanding how entrepreneurs build their decision-making logic. The causation principle underlies a cause-effect relationship in the behavior of entrepreneurs and a careful planning of their undertaking, while effectuation draws on a more flexible, adaptive and experimental strategies (Fisher, 2012). Despite the conceptual difference between those two logics, Sarasvathy (2008) stated that "both decision-making logics are integral parts of human reasoning and can occur simultaneously, overlapping and intertwining over different contexts of decisions and actions". Entrepreneurs can thus prefer and use effectual and causal reasoning at different times, depending on what the circumstances and their individual preferences call for (Gabrielsson $\&$ Politis 2011).

Thus, in this paper we are interested in examining whether being a female entrepreneur may make them more in favor of one decision-making logic over another. We also set to investigate to what extent female entrepreneurs' decision making may vary according to the underlying motives of their entrepreneurial process.

\section{Female Entrepreneurship}

Entrepreneurship has long been considered a male activity. Although the number of women entrepreneurs is steadily rising, it remains lower than that of men. An important question is whether women entrepreneurs face specific problems in setting up a business that are different from those faced by male entrepreneurs.

Previous research on women's entrepreneurship has identified five areas in which there are differences between male and female entrepreneurs: The motivations for starting a business, the work-family relationship, management style, networking and access to the workplace (Fairlie \& Robb, 2009). Women entrepreneurs is a heterogeneous group, with multiple realities. Women are different because of their personal characteristics, the type of business they will create and the type of financing they will seek. 


\section{Entrepreneurial Motivation of Women}

Several studies have focused on distinguishing between the motivation of male and female entrepreneurs. Research shows that women's entrepreneurial motivations are mainly based on positive factors such as: Taking up a challenge, living in a pleasant work environment, being independent to which are added in a pregnant way, the balance factor between family and work (Kirkwood, 2009). It is then, to be noted that the panorama of female entrepreneurship is complex, and different motivational profiles can coexist. Building from a collection of articles in female entrepreneurial motivation, and by analyzing the main typologies of female entrepreneurship. D'Andria and Gabarret (2016) identified three figures or ideal types (which appear mainly in research and over time): Necessity-driven women entrepreneurs, career woman entrepreneurs (or in transition to entrepreneurship) and women who are creating companies at the time of maternity (mumpreneurs).

\section{Necessity-Driven Entrepreneurship}

Women entrepreneurs who are necessity-driven act mainly for economic reasons. Their motivations are essentially to ensure their subsistence, to compensate for an unemployment situation or the impossibility of finding a job, or circumventing practices of discrimination or marginalization. In these conditions, necessity-driven entrepreneurship is a means to ensure satisfaction of primary needs of the individual. However, compared to men, women have more barriers to employment. They are, the latest to be hired and the first to be fired (Elam \& Terjesen, 2010). So, they are forced to start their own business because of a lack of employment or unsatisfactory employment and for which remuneration is often not sufficient to ensure the survival of the individual or his primary family group.

\section{Women Entrepreneurship as a Career Transition}

Another group of research focused on women who already having a job, decide to start a business. The reasons may be related to job dissatisfaction, including the glass ceiling, or the search for fulfillment through an entrepreneurial career.

This category of women entrepreneurs brings together the cases of women who are not in a creation due to economic necessity or having work-family balance. In this type of entrepreneurship there are women who voluntarily and without being driven by circumstances, have chosen to start their own business. Some will consider entrepreneurship directly as a career, creating companies as soon as they leave school, others will think of entrepreneurship as a continuation of their professionnal career (d'Andria, 2014).

\section{Women Entrepreneurship as a Quest for Work- Family Balance: The Figure of the Mumpreneur}

Although the work-family balance has been addressed in the case of women's work, a growing literature has emerged in recent years, identifying the figure of mumpreneurs: Mom and entrepreneur considered as new figures in female entrepreneurship (d'Andria, 2014).

Identifying herself as both a mother and a businesswoman, the mumpreneur decides to launch a new organization of which she is the owner and manager, in order to achieve a professional and private balance that is difficult if not impossible as an employee. The business opportunity is generally related to the particular experience of having children (Richomme-Huet, Vial, \& d'Andria, 2013). According to Korsgaard (2007), the main motivation of mumpreneurs is to reconcile work and family life, to find a balance between their career and the needs of their family. For Duberley and Carrigan (2013), these women engage in entrepreneurship when a child comes, in order to become independent and escape the idea of being seen as stay-at-home moms.

\section{Decision-Making Logic}

Sarasvathy (2008) proposed causation and effectuation logics of decision making, defined as follows: "Causation processes take a particular effect as given and focus on selecting between means to create that effect. Effectuation processes take a set of means as given and focus on selecting between possible effects that can be created with that set of means". The author implies that the logic applied by decision-makers results from their beliefs and perceptions of the future phenomena. If decision makers perceive the future as predictable, they will tend to apply a causation logic; if not, they will apply an effectuation logic. Sarasvathy (2008) uses the preparation of a meal as an analogy. In the case of causation, a meal is chosen and he chef tries to find the required ingredients and kitchen utensils and then prepares exactly that meal. In the case of effectuation, however, the chef has no particular meal in mind but rather goes through the cupboards to see which ingredients and utensils are available and then prepares a meal based on that as one of multiple options (Hinz, 2017). These two logics are characterized with different sets of principle. 


\section{Causation}

The causal logic, largely inspired by rational choice theories (Corner \& Ho, 2010; Perry et al., 2012), allows the optimal selection of resources needed to achieve a pre-existing goal (Sarasvathy, 2008). The causal logic is based on the belief that the future can be predicted by rational techniques of analysis or estimation. It involves making decisions based on profitability calculations, and actions to avoid unexpected events. The causation principles are (1) maximization of the expected returns and focus on optimal decision, (2) competitive analysis, (3) exploitation of pre-existing knowledge, and (4) focus on predictable aspects of uncertain future.

\section{Effectuation}

Based on a study successful entrepreneurs, Sarasvathy (2008) comes with the conclusion that most entrepreneurs start with a fairly simple idea, or no idea at all (Silberzahn, 2016). The objectives of the entrepreneurs, will often emerge, in a very pragmatic way, as and when the progress of his entrepreneurial project.

\section{Table 1}

Causation and Effectuation Logic Contrasted Against Each Other (Gabrielsson \& Politis, 2011)

\begin{tabular}{|c|c|c|}
\hline & Causation & Effectuation \\
\hline $\begin{array}{l}\text { Nature of } \\
\text { Unknowns }\end{array}$ & $\begin{array}{l}\text { Focus on predictable } \\
\text { aspects of an } \\
\text { uncertain future. }\end{array}$ & $\begin{array}{l}\text { Focus on control- } \\
\text { lable aspects of an } \\
\text { unpredictable future. }\end{array}$ \\
\hline $\begin{array}{l}\text { Market } \\
\text { Definition }\end{array}$ & $\begin{array}{l}\text { Using techniques of } \\
\text { analysis and } \\
\text { estimation to explore } \\
\text { and exploit existing } \\
\text { and latent markets. }\end{array}$ & $\begin{array}{l}\text { Using synthesis and } \\
\text { imagination to create } \\
\text { new markets that do } \\
\text { not already exist. }\end{array}$ \\
\hline Goal Orientation & $\begin{array}{l}\text { Seeking to identify } \\
\text { the optimal } \\
\text { alternative to achieve } \\
\text { a given goal. }\end{array}$ & $\begin{array}{l}\text { Allowing goals to } \\
\text { emerge contingently } \\
\text { e over time. }\end{array}$ \\
\hline $\begin{array}{l}\text { Relation to } \\
\text { Uncertainty }\end{array}$ & $\begin{array}{l}\text { Avoiding uncertain } \\
\text { situations to the } \\
\text { greatest possible } \\
\text { extent. }\end{array}$ & $\begin{array}{l}\text { Seeking uncertain } \\
\text { situations in the hope } \\
\text { of being able to } \\
\text { exploit them. }\end{array}$ \\
\hline $\begin{array}{l}\text { Stakeholder } \\
\text { Relationships }\end{array}$ & $\begin{array}{l}\text { Goal-oriented } \\
\text { relationships with } \\
\text { strategically selected } \\
\text { stakeholders }\end{array}$ & $\begin{array}{l}\text { Means-oriented } \\
\text { relationships with } \\
\text { self-selected } \\
\text { stakeholders }\end{array}$ \\
\hline Market Research & $\begin{array}{l}\text { Pre-calculated and } \\
\text { detailed competitive } \\
\text { analyses for } \\
\text { investigating the } \\
\text { need for or interest in } \\
\text { product or service. }\end{array}$ & $\begin{array}{l}\text { Informal methods } \\
\text { for investigating the } \\
\text { need for or interest in } \\
\text { product or service. }\end{array}$ \\
\hline
\end{tabular}

It is often then step by step, according to his desires, the encounters he makes, the networks he knows how to mobilize ... and by solving difficulties as they arise, that the entrepreneur shapes his entrepreneurial project (Sarasvathy \& Germain, 2011).

Effectuation theory challenges the concept of the strictly rational and well-informed entrepreneur who follows the formal, rational decision-making procedures. In a sense, effectuation theory presents a more refined differentiation between linear decision making (based on analytical reasoning and factual analysis) and nonlinear decision making (based on intuition, creativity, insight and emotions) (Groves, Vance, \& Choi, 2011).

The effectuation principles are (1) affordable loss and focus on experimentation, (2) strategic alliances and stakeholders (to reduce/eliminate uncertainty and build entry barriers), (3) exploitation of contingencies, (4) focus on controlling an unpredictable future (Sarasvathy, 2008).

\section{Research Method}

Since our main objective is to understand the decision-making logic of women entrepreneurs, a qualitative exploratory methodology was adopted. Ten in-depth interviews were conducted among female entrepreneurs. We explored three themes in particular: (1) the origin of their entrepreneurial project. Specifically, we aimed at understanding when and how they decided to start their own business? Their motivation to go through this process and the way they dealt in the early stages of the project. (2) The implementation of the business, in order to understand the steps through which they've gone, the difficulties they encountered, how they managed them and their decision-making process in this entrepreneurial path (3) The management of their business. We sought in this theme to understand how they daily manage their business. Their relationship with their environment, relation to risk and uncertainty.

Data were analyzed through a thematic content analysis. The discourse of our respondents were analyzed and categorized following a pre-determined coding scheme, built on the distinctive characteristics of effectuation vs causation logic. The frequency of occurrence within one or the other category, then allowed us to define whether our respondents were rather to be categorized as having a more effectual rather than causal logic.

\section{Result}

Results show causation logic and effectual logic were mobilized by women entrepreneurs. The orientation for effectual or causal logic were determine by: Entrepreneurial expertise and entrepreneurial uncer- 
tainty. Our result also points out the link between entrepreneurial motivation and the preference for causal rather than effectual logic. More, and consistent with previous research our result show that women entrepreneurs sometimes follow a hybrid approach, by combining elements of causation and effectuation. We will present our main results by laying the emphasis on the case of three of our respondents, each illustrating in their own way the three axes of our findings.

\section{Causation Decision-Making: The Case of KB, a Novice Necessity-Driven Entrepreneur}

KB started her business a year ago after losing her law practice at a law firm where she worked for 20 years. This was the opportunity for her to embark on the creation of a company. A project she had in mind but for which she did not dare to take the plunge, as long as she was still in her comfort of "employee ". She is 53, single and has a girl.

Analysis of her discourse points outs that her dominant mode of decision making is the causation framing. She had a clearly rational approach. Her business was launched, after a whole process of market studies, definitions of needs and a set of actions to reduce risk perception.

"Before I started, I needed to make sure I had a pool of potential customers. I contacted all the old clients I had in my former office, to see if some would be ready to follow me."

This verbatim illustrate an aspect of the pure rationality of her actions. This shed a light on her need to avoid uncertainty and also her risk-aversion.

\section{The Causation Principles Applied to KB Focus on Predictable Aspects of an Uncertain Future}

According to the causation framing, entrepreneurs will try to "control the future", by focalizing on element they master most. As stated by KB:

"I did not like to venture into the unknown. So, I chose to start my business in a field that I knew well and for which I had evaluated the potential market."

\section{Using Techniques of Analysis and Estimation to} Explore and Exploit Existing and Latent Markets

The causal logic, allows the optimal selection of resources needed to reach a pre-requisite.

"I evaluated my project well. I knew that the demand was strong, having already worked in this area. I had to really define what I wanted to do in relation to my skills. With the migration problems currently in France, I knew that I was embarking on a promising area."
Causal logic is based on the belief that the future can be predicted by rational analysis techniques. With the words of Hinz (2017), "Business planning, is part of causation along with competitor analyses in order to predict an uncertain future."

\section{Effectuation Logic: The Ase of RB, a Career- Transition Expert Entrepreneur}

After a long career in the field of training and consulting, RB saw the opportunity to start her own business when the company who employed her started having some difficulties. By capitalizing on her experience and client portfolio, she quickly decided to take the leap in entrepreneurship by starting her own business in her area of expertise. This was 23 years ago. Behind this first company, she is collaborating with several entrepreneurs in the process of creating their firms. She is 60, married and no child.

"I quickly set up my business. I built everything from what I had: my skills, my relationships, my madness ... and I said to myself: "you throw yourself in the water and you will learn to swim at the same time."”

These words used by RB to describe how she launched echoed the analogy used by Sarasvathy (2008) to describe how effectual logic works compare to causation logic. RB in this case, acts as the "chef who having no particular meal in mind, prepares a meal from what he finds in his kitchen" (Hinz, 2017).

\section{The Effectuation Principles Applied to RB}

From what she said during the interview, we figured out the link between her behavior and some principles building the effectual logic.

\section{Affordable Loss and Focus on Experimentation}

RB started her business with the idea of "trying something". She started with her ow savings, since she was not really "knowing what she was up to". As she puts it:

"I launched my business without really thinking about... I didn't know I would have customers. But I never saw this as a risk, but rather as an opportunity.

\section{Strategic Alliances and Stakeholders}

Ideally, the transformation of the first customers into strategic partners is a guarantee of market consolidation in the creation of the company. This worked for RB: 
"A week after I started my business, I ran into a former client of my old company. I told him that I had just started my own business. A week later, he called me and I signed my first big contract.... He gave me the boost."

Thus, confirming the fact that "effectuation emphasizes strategic alliances with customers and other stakeholders as well as their pre-commitments to gain control of an unpredictable future (Hinz, 2017).

\section{Exploitation of Contingencies}

Far from avoiding surprises, RB knows how to welcome the unexpected. Trying to changing them into opportunities. Table below sums up some of the verbatim used by those two respondents. Those verbatim allowed us to figure out their preferred mode of decision-making (causation vs effectuation).

Table 2

Causation vs Effectuation Logic Illustrated with Verbatim

\begin{tabular}{|c|c|c|}
\hline & $\begin{array}{l}\text { KB (Causation } \\
\text { Dominated) }\end{array}$ & $\begin{array}{l}\text { RB (Effectuation } \\
\text { Dominated) }\end{array}$ \\
\hline $\begin{array}{l}\text { Nature of } \\
\text { Unknowns }\end{array}$ & $\begin{array}{l}\text { I did not like to } \\
\text { venture into the } \\
\text { unknown. So I } \\
\text { chose to start my } \\
\text { business in a field } \\
\text { that I knew well } \\
\text { and for which I had } \\
\text { evaluated the } \\
\text { potential market }\end{array}$ & $\begin{array}{l}\text { The unexpected does } \\
\text { not scare me. I started } \\
\text { without really knowing } \\
\text { where I was going, but I } \\
\text { have absolute } \\
\text { confidence in my } \\
\text { abilities and it's a } \\
\text { challenge for me to } \\
\text { always get there }\end{array}$ \\
\hline Market & I evaluated my & You have to constantly \\
\hline Definition & $\begin{array}{l}\text { project well. I knew } \\
\text { that the demand } \\
\text { was strong, having } \\
\text { already worked in } \\
\text { this area. I had to } \\
\text { really define what I } \\
\text { want to do in } \\
\text { relation to my skills. } \\
\text { With the migration } \\
\text { problems currently } \\
\text { in France, I knew } \\
\text { that I was } \\
\text { embarking on a } \\
\text { promising area. }\end{array}$ & $\begin{array}{l}\text { renew yourself and not } \\
\text { be afraid to come up } \\
\text { with new things. I was } \\
\text { talking with a client who } \\
\text { told me about the } \\
\text { changes to make in his } \\
\text { company ... I } \\
\text { immediately offered to } \\
\text { accompany him in } \\
\text { managing change ... yet } \\
\text { at the time it was not } \\
\text { something very well } \\
\text { known. }\end{array}$ \\
\hline Goal & I have everything & I do not set limits ... \\
\hline Orientation & $\begin{array}{l}\text { defined upstream } \\
\text { It took me a year, } \\
\text { from when I had the } \\
\text { idea to get started } \\
\text { and when I did it. I } \\
\text { needed to clarify my } \\
\text { goals, set clear and } \\
\text { attainable goals, and } \\
\text { evaluate all the }\end{array}$ & $\begin{array}{l}\text { Depending on my en- } \\
\text { counters, the needs that I } \\
\text { meet with my clients or } \\
\text { elsewhere, I expand my } \\
\text { training offer. }\end{array}$ \\
\hline
\end{tabular}

alternatives open to

me.

Relation to I took a year to get My sporting side really

Uncertainty started, because I takes me to the constant really had to make search for the surpassing the most possible of oneself. That's why I guard, I did not have no doubt about my want to go blind. I ability to do things right do not much like ... and for me what you taking non- call risk is an calculated risks. opportunity.

Stakeholder I relied heavily on I rely on a solid team Relationships my network from that has been with me my previous firm. for 23 years ... It is also my former I never considered boss who gave me associating with people my first clients ... ... I did not really need it.

Market I took the time to I am a lot in the

Research study the market. relationship. I think we my clients are often learn more in informal in a precarious situa- discussions. Instead of tion ... I studied all studying the needs of the possibilities that the competition and all they had to be able this stuff in the books, I to pay my benefits grow my network and ... I do not take believe me it's worth all uncalculated risks. your books.

\section{Hybrid Approach: The Case of CP, a Novice Mumpreneur}

$\mathrm{CP}$ holds a $\mathrm{PhD}$ in Management Science. Not having found a position corresponding to her aspirations and not very interested in teaching, she had the trigger at the birth of her daughter. She decided to start her own business in order to be more independent. It's only been nine months since she started this entrepreneurial process. She is 36. She follows both causation and effectuation principles.

She is in the early stages of development of her business, without former entrepreneurial expertise, and alternates between (1) the need to limit the risks as much as possible "I contacted several organizations that helped me build my project. I also took courses on entrepreneurship" and (2) the desire to take risks to open new horizons. "It seemed to me more relevant to create my own company because it allowed me to be autonomous and to offer a service that suited me". She acts, clearly in an effectual way as far as these effectual principles are considered.

\section{Means}

Entrepreneurs have certain means at their disposal that they can put to use by engaging in effectual behavior; these are articulated as "what I know" and "who I am" (Read, Song, \& Smith, 2009) "I wanted 
to become an associate professor. Not having obtained a position, I decided to turn to an activity that I have always liked and that attracted me: Events creation. Indeed, my training brought me to know the environment of tourism. First of all, I had a degree in Management of touristic activities. I've then been graduated in Tourism and Hotel management. My $P h D$ works were also dedicated to the event sector. So, in the absence of a job as associate lecturer in a university, I've decided to go back on my first center of interest" With this statement, CP clearly behaves "effectually". Entrepreneurship was not her first choice, but when it came to consider creating her own business, the primary resources she built on were the "what I know" and "who I am". She identified categories of means related to "what I know" which are relevant to the venture (Hinz, 2017).

\section{Exploitation of Contingencies}

$\mathrm{CP}$ also has an effectual approach as far as the exploitation of contingencies principles is concerned. Instead of pursuing a clearly defined goal as in the case of causation, leveraging contingencies emphasizes innovative applications of contingent alternatives which entrepreneurs encounter while using what they have at their disposal and engaging in the entrepreneurial process of creation (Read, Song, \& Smith, 2009) "For now, I still have uncertainties about the definitive offer that I will propose. I set goals initially but they have evolved over time depending on the difficulties encountered. I try to adapt, and to adapt my project to the contingencies I am faced with."

Being mostly effectual concerning the definition of the project and the relation to uncertainty and exploitation of contingencies, $\mathrm{CP}$ adopts a more causal approach, when it is about implementing the project, with quite a scholastic approach.

"I did intensive researches, to clearly identify the competitors, their offer... the customers' needs...I needed this in order to have a clear idea of what I was ahead to...to define my offer."

\section{Discussion}

This research is an exploratory approach to understand decision-making process of women entrepreneurs. In this study, we examined the decisionmaking logic of women entrepreneurs in regard to effectual and causal logics. Our research points our two different profile of women entrepreneur, having distinct preferred decision-making logic. Profile one, is represented by $\mathrm{KB}$, a novice and necessity-driven entrepreneur, who is more on a causation approach, being a novice entrepreneur, she feels herself in a context of entrepreneurial uncertainty, thus she applies a causal approach in order to sset up all the possible safeguards to limit the risk of failure. Profile two, is represented by RB an expert an opportunitydriven entrepreneur having effectuation as the preferred mode of decision-making. RB feels "she was born an entrepreneur". She went into her entrepreneurship path with a means-driven strategy, with no specific business plan and a vague goal. And then exploiting all the opportunities available to her to achieve success.

These are consistent with the work of Dew, Read, Sarasvathy, and Wiltbank (2009) who show that entrepreneurial experts tend in the process of business creation to use more effectuation reasoning (due to greater depth of knowledge allowing them to rely on recurrent patterns), whereas novice entrepreneurs will employ causation framing depending on indepth planning and controllling. Further, this research points out a hybrid decision making approach, consistently with Reymen et al. (2015), who showed that entrepreneurial decision-making often follows a hybrid approach, combining aspect of causation with elements of effectuation. Moreover, this study seems to point a link between decision-making logic and motivation of women entrepreneurs. Necessity-driven female entrepreneurs having a causal logic, career transition entrepreneurs being effectual and mumpreneurs having a hybrid approach. This last point contrasting with the works of d'Andria (2014), who concludes that mumpreneurs are preferably effectual in their decision-making.

\section{Conclusion}

The exploratory nature of this research opens the way to several limitations, which are also potential orientations for further research. First, our research method being qualitative, does not allow a clear verification of the theory elaborated here. This limit could be addressed by going further to this exploratory task, by drawing formal hypotheses that could be empirically tested. In addition, the link between decision-making logic and motivation of women entrepreneurs having no further theoretical background, need to be assessed in other contexts, or tested empirically, in order to be validated. The entire results are built on three cases, it would be certainly useful to duplicate this with more cases, more profile of women entrepreneurs in order to test de solidity of this proposition. 


\section{References}

Corner, P. D., \& Ho, M. (2010). How opportunities develop in social entrepreneurship. Entrepreneurship Theory and Practice, 34(4), 635-659.

D'Andria, A. (2014). Un éclairage sur le processus entrepreneurial des mampreneurs. Étude exploratoire de leur dynamique effectuale. Revue de l'Entrepreneuriat, 13(1), 11-33.

D'Andria, A., \& Gabarret, I. (2016). Femmes et entrepreneurs: Trente ans de recherches en motivation entrepreneuriale féminine. Revue de l'Entrepreneuriat, 15(3-4), 87-107.

Dew, N., Read, S., Sarasvathy, S. D., \& Wiltbank, R. (2009). Effectual versus predictive logics in entrepreneurial decision-making: Differences between experts and novices. Journal of Business Venturing, 24(4), 287 -309.

Duberley, J., \& Carrigan, M. (2013). The career identities of 'mumpreneurs': Women's experiences of combining enterprise and motherhood. International Small Business Journal: Researching Entrepreneurship, 31(6), 629-651.

Elam, A., \& Terjesen, S. (2010). Gendered institutions and cross-national patterns of business creation for men and women. European Journal of Development Research, 22(3), 331-348.

Fairlie, R. W., \& Robb, A. M. (2009). Gender differences in business performance: Evidence from the characteristics of business owners survey. Small Business Economics, 33(3), 375-395.

Fisher, G. (2012). Effectuation, causation, and bricolage: A behavioral comparison of emerging theories in entrepreneurship research. Entrepreneurship Theory and Practice, 36(5), 10191051.

Gabrielsson, J., \& Politis, D. (2011). Career motives and entrepreneurial decision-making: Examining preferences for causal and effectual logics in the early stage of new ventures. Small Business Economics, 36(3), 281-298.
Groves, K., Vance, C., \& Choi, D. (2011). Examining entrepreneurial cognition: An occupational analysis of balanced linear and nonlinear thinking and entrepreneurship success. Journal of Small Business Management, 49(3), 438-466.

Hinz, A. (2017). Entrepreneurial behaviour revisited: Linking self-efficacy with effectuation. International Journal of Business and Society, 18 (2), 245-260.

Kirkwood, J. (2009). Motivational factors in a pushpull theory of entrepreneurship. Gender in Management: An International Journal, 2(5), 346-364.

Korsgaard, S. (2007). Mompreneurship as a challenge to the growth ideology of entrepreneurship. Kontur, 16, 42-45.

Perry, J. T., Chandler, G. N., \& Markova, G. (2012). Entrepreneurial effectuation: A review and suggestions for future research. Entrepreneurship Theory and Practice, 36(4), 837-861.

Read, S., Song, M., \& Smit, W. (2009). A metaanalytic review of effectuation and venture performance. Journal of Business Venturing, 24(6), 573-587.

Reymen, I. M., Andries, P., Berends, H., Mauer, R., Stephan, U., \& Burg, E. (2015). Understanding dynamics of strategic decision making in venture creation: A process study of effectuation and causation. Strategic Entrepreneurship Journal, 9(4), 351-379.

Richomme-Huet, K., Vial, V., \& d'Andria, A. (2013). Mumpreneurship: A new concept for an old phenomenon? International Journal of Entrepreneurship and Small Business, 19(2), 251-275.

Sarasvathy, S. D. (2008). Effectuation: Elements of entrepreneurial expertise. Cheltenham, UK: Edward Elgar.

Sarasvathy, S. D., \& Germain, O. (2011). L'effectuation, une approche pragmatique et pragmatiste de l'entrepreneuriat. Revue de l'entrepreneuriat, $10(3), 67-72$.

Silberzahn, P. (2016). L'effectuation, logique de pensée des entrepreneurs experts. Entreprendre \& Innover, 28(1), 76-82. 